\title{
Implication of Technology Adoption on Economic Returns of Women Melon Processors in North Central, Nigeria
}

\author{
Oyediran, Wasiu Oyeleke ${ }^{1 *}$; Omoare, Ayodeji Motunrayo ${ }^{2}$ Oyekunle, Olanrewaju Opeyemi ${ }^{3}$ and \\ Abubakar, Abubakar Alhaji ${ }^{3}$ \\ ${ }^{1}$ Department of Agricultural Extension and Rural Development, Federal University of Agriculture, Abeokuta, \\ Nigeria \\ ${ }^{2}$ Department of Agricultural Education, Federal College of Education, Abeokuta, Ogun State, Nigeria \\ ${ }^{3}$ Department of Agricultural Economics and Extension Services, Ibrahim Badamasi Babangida University, Lapai, \\ Niger State, Nigeria \\ *Email: oyediran_wasiu@yahoo.com
}

\begin{abstract}
Melon (Citrillus colocynthis L.) is processed into diverse products for rural households' consumption as food and to generate higher economic returns. However, the prevailing traditional processing techniques cannot substantially minimize drudgery, seed spoilage and economic losses. This study was carried out to examine implication of technology adoption on economic returns of melon processors in North Central, Nigeria. One hundred and ninety melon processors were randomly selected from ten villages as the sample size for this study. Descriptive statistics and linear regression were used for the data analysis. About sixty-five percent of the respondents processed less than $2.52 \mathrm{~kg}$ of melon in a day before the introduction of improved melon sheller while most (80.0\%) of the respondents processed more than $190 \mathrm{~kg}$ in a day with improved technology. Gross Margin (GM) estimated for hand shelled melon was $\$ 2,230.01$ /week compare to $\$ 47,530.00$ /week obtained from melon sheller. Result of t-test indicates a significant difference in the melon processed before and after technology adoption $(\mathrm{t}=-22.27, \mathrm{p}=0.02)$ at $\mathrm{p}<0.05$ level of significance. It can be concluded that adoption of improved melon processing technology led to increase in production output and higher economic returns. The study therefore recommends that rural women should continue to adopt improved melon processing technology for higher productivity and economic returns.
\end{abstract}

Keywords: Implication, improved technology, adoption, melon, economic returns

\section{Introduction}

Melon (Citrillus colocynthis L.) which is widely known as egusi in West African countries belongs to the family of curcurbitaceae and it is planted for its' seed oil (Mohammed, 2011). Sobowale, Adebiyi and Adebo (2015) reported that melon is the fourth most important horticultural crop in the world in terms of production $(18,000 \mathrm{MT})$. Furthermore, it is a fact that Nigeria is having abundant rich farmlands and subsequent bumper harvest especially during wet season but the country is experiencing high postproduction losses. The country is one of the leading producers of melon and other vegetables that are grown in its diverse agro-ecological zones that range from humid in the South to sub-humid in the middle belt and semi-arid/arid in the North (Ayodele and Shittu, 2013). The processing of melon is imperative to diversify its uses. However, the current handling and traditional processing techniques cannot substantially minimize drudgery, seed spoilage, and losses, which consequently affect quantity and quality of melon supply. Traditional methods are constrained by reliance on manual operations. The methods do not only bring-about serious human drudgery with little achievements but discourage timeliness and perfection (James Umogbai and Itodo, 2011). The methods include fermentation, sun drying, shelling, and cooking. This is predominantly in the hands of a multitude of small-scale, unorganized processors scattered across the country. Rather than focusing almost entirely on traditional methods, research should also explore postharvest losses reduction strategies, better marketing techniques with a view to help rural women in the melon value chain increase and sustain melon as a business. Achieving growth in agricultural productivity will not be possible without developing and disseminating output-increasing technologies and application of these technologies by rural households. 
According to Ross (2012), the developed countries of the world such as United States, Germany, Netherland, Japan, China, Sweden, and Switzerland have become self-sufficiency at food production and processing for standardization and international trading for over three decades. The paradigm shift from traditional method to modern processing techniques in developed countries has made a landmark in their agricultural sector. Ofoh (2009) stated that an important area that requires urgent attention in developing countries is the area of post-production handling; this is to reduce spoilage, waste and other losses in quantity and quality of farm produce between the time of harvesting and time of marketing and consumption. Most studies on post-production handling have so far concentrated on grains and tubers and significant improvement had been achieved on post-production handling of these crops in the last decades (Atanda Pessu, Agoda, Isong and Ikotun, 2011). It has been observed that little attention is given to melon; in this regard it is often considered as a minor oil crop (Ajibola Eniyemo, Fasina and Adeeko, 1990). In spite of this, its contribution to the nutritional diet and economic empowerment of rural dwellers especially among women has not been given appropriate consideration in post-production researches. Taking a careful look at the usefulness of melon seeds, there is a need for efficient means of processing it. The actual situation in the rural areas of Nigeria indicates the need for low-cost technology to produce, process and add-value while maintaining quality of melon products (oil and cake). The wide application of proven technologies and approaches to indigenous knowledge of processing, marketing and utilization of melon could contribute to the reduction of stress and food losses. Obviously, improved melon processing determines quality, safety, competitiveness in the market, and the profits earned by processors. The users' benefit from the adoption of improved technology through opportunities to lower their production costs, either by increasing outputs or by maintaining the same output from reduced inputs. These technologies include the application of deppoder, washer, sheller, dryer, grinder, and oil-extractor to melon processing operations (Thisdaylive, 2013; Onwualu, 2010). The adoption rate of these improved technologies however remains very low among the rural women thus limiting the purpose of which they are meant for (Mohammed Achem and Abdulquadri, 2014). It has been reported that personal issues such as gender, availability of resources required for the use of innovations, priority and benefits expected to be gained motivate rural dwellers to adopt innovations (Aniedu, 2006). Working with women in this study is, therefore, to assess their contributions to increase melon supply, value addition and food safety through improved processing technology, which reduce postharvest losses and women stress during processing of melon. The idea is to tap into women's roles as income-earners and food producers on the one hand, and as food processors and care givers on the other. Since eradicating malnutrition is an effective investment in the human capital of a country, rural women are the key group requiring attention in agricultural and rural development. Increasing their productivity and income by bridging the technology gap in melon processing can make a major contribution to reducing hunger, unemployment and poverty. Economic growth in the agricultural sector is twice as effective in reducing poverty as growth in other sectors of the economy (World Bank, 2009). According to Ayittey (2005), three out of four Africans are engaged in agriculture, with women making the most significant contribution. Women perform some 90 percent of the work of food processing, 80 percent of food storage tasks, and 60 percent of harvesting and marketing; they play a key role in food production, food security and the sustainability of Nigeria economy. It was based on this premise that this study assessed implication of improved melon processing technology on economic returns of the rural women in North Central, Nigeria; estimated the quantity of melon processed and sales made per week before and after the introduction of technology; and assessed the usefulness and benefits of improved melon processing technology.

\section{Hypothesis of the Study}

$\mathrm{H}_{01}$ : there is no significance difference in the melon processed before and after the technology adoption $\mathrm{H}_{02}$ : There is no significant relationship between quantity of melon processed with improved technology and economic returns in the study areas.

\section{Description of the Study Area}




\subsection{North Central}

North central is one of the six geo-political zones in Nigeria and it comprises of six states which are Benue, Plateau, Kogi, Kwara, Nassarawa, and Niger States. This study was conducted in Niger State which is the largest of the six states and agriculture is prominent practice among the citizens in the state, and its population was 4,082,558 (National Population Census (NPC), 2006). The state was created in 1976 with its capital in Minna. It is located between latitudes $8^{\circ} 20^{\prime} \mathrm{N}$ and $11^{\circ} 30^{\prime} \mathrm{N}$ and longitudes $3^{\circ} 30^{\prime} \mathrm{E}$ and $7^{\circ} 20^{\prime} \mathrm{E}$. Currently, the state covers a total land area of $76,000 \mathrm{~km}^{2}$ (about 9 percent of Nigeria's total land area). This makes it the largest state in the country (Community Portal of Nigeria, 2003). The vegetation consists of short grasses, shrubs, and scattered trees. By reason of its location and its climate, soil, and hydrology, Niger State has the capacity to produce most of Nigeria's staple crops such as maize, sorghum, rice, yam, pepper, and melon. Agriculture is the back bone of the economy of Niger State as nearly 90 percent of the population depends either directly or indirectly on it for their livelihood (Community Portal of Nigeria, 2003). The study area is appropriately deriving from the fact that farming constitutes the primary occupation of the rural women in the study area. In Niger state, melon is second to rice as major crop cultivated and it is produced in large quantity to the extent that many melon traders across the country go to the state to purchase melon. It forms important part of the diet of the people, empowerment, source of income, and gifts in these areas.

\subsection{Sampling Procedure and Sample Size}

Simple random sampling technique was used in selecting five Local Government Areas (LGAs) out of twenty-five (25) LGAs. The selected Local Government Areas were Lapai, Katcha, Agaei, Lavun and Gbako. Melon is the major crop cultivated in these areas. In each of the LGAs two villages were randomly selected making 10 villages. Nineteen melon processors were randomly selected from each of the villages making a total of one hundred and ninety (190) melon processors selected as the sample size for this study.

\subsection{Measurement of Variables}

The economic returns realized from the processed melon were estimated using Gross Margin (GM) technique. That is, subtraction of Total Variable Costs (TVC) from the Gross Income (GI). Gross Income is the estimated weekly sales of processed melon. TVC encompasses transportation fares, market levy and miscellaneous expenses. TVC and GI were measured in ( $\mathrm{N} /$ week).

$\mathrm{GM}=\mathrm{GI}-\mathrm{TVC}$

where;

GI - Sales/week from processed melon seeds

TVC - Total Variable Cost

Descriptive statistics, regression analysis and t-test were used for the data analysis.

\section{Results and Discussion}

\subsection{Quantity of Melon Processed before and after the Introduction of Technology}

Processing of agricultural produce is a major traditional responsibility of rural women in Sub-Saharan African countries; it is in this area of food processing that women, particularly in Nigeria are mostly distinguished. The result in Table 1 reveals that majority $(64.7 \%)$ of the respondents processed less than $2.52 \mathrm{~kg}$ in a day before the introduction of improved melon Sheller while $35.3 \%$ of the respondents stated that they processed $3.78-5.04 \mathrm{~kg}$ in a day if the children join hands with them in the shelling of melon. With regards to improved melon Sheller, most (80\%) of the respondents reported that they produced more than $190 \mathrm{~kg}$ in a day while $19.6 \%$ of the respondents produced between $126-189 \mathrm{kga}$ day. The observed variation in quantity of melon processed is a pointer to the available processing facilities and types of technologies being used by the respondents in the study areas. That is, the higher output of processed melon is attributed to the use of improved melon processing technology by adopters than to 
the low output from traditional method of hand shelling. This implies that production level increased after adopting the improved technology and it will have multiplier effect on the economic returns and the well-being of melon processors in the study areas. The introduction of western technology to nonwestern farmers is intended to increase production capacity and improve the market position of agriculture. Hart, Ajubuike, Barimaala and Achienwhu (2005) affirm that the improved technology contributes to agricultural development in terms of increased production output, high income, and improved standard of living. This finding also agrees with that of Donkoh (2006) who identified a positive relationship between productivity and intensity of adoption of the improved technology.

Table 1: Quantity of Melon Processed before and after the introduction of Improved Melon Sheller $(\mathrm{n}=190)$

\begin{tabular}{llll}
\hline Before & \multicolumn{3}{l}{ After } \\
\hline Quantity of processed melon $(\mathrm{kg} /$ day $)$ & FP & Quantity of processed melon $(\mathrm{kg} /$ day $)$ & FP \\
\hline$\leqslant 2.52$ & $123(64.70)$ & $126-189$ & $37(19.50)$ \\
$3.78-5.04$ & $67(35.30)$ & $\geqslant 190$ & $153(80.50)$ \\
\hline
\end{tabular}

Source: Field survey, 2016 FP - frequency and percentage

1 mudu of shelled melon approximately weighed $1.26 \mathrm{~kg}$

\subsection{Economic Returns from Processed Melon}

The economic returns for processed melon with improved technology were presented in Table 2. The average market price of shelled melon was $\$ 450.00 / m u d u$. Similarly, average output of shelled melon was approximately 300 mudus per week. The total variable cost incurred on shelled melon was \$87,570.00/week while the estimated total revenue was $\$ 135,000 /$ week. Meanwhile, the Gross Margin (GM) was $\$ 47,530.00 /$ week. This implies that adoption of improved technology has impacted positively on the economic returns of melon processors, thereby increasing their probability of escaping economic hardship and poverty. This is in line with the findings of Fadilah, Seth and Seidu (2013) that productivity-enhancing agricultural innovations can contribute to raising incomes of rural households, poverty alleviation, food security and better well-being in developing countries. Terlin, (2003) cited in Nwanyanwu et al. (2014) reported that monthly income generated in over 18 African countries adopting modernized agricultural practices was $40 \%$ more than those practicing traditional methods. Ezeh and Nwachukwu, (2007) examined "The Impact of Selected Rural Development Programmes on Poverty Alleviation in Abia State, Nigeria", it was found that the participating farmers performed better in terms of income and output compared to their counterparts. Therefore, improvement in economic returns will further encourage adoption of introduced modern processing technology by the melon processors and marketers.

Table 2: Estimation of economic returns

\begin{tabular}{|c|c|}
\hline $\begin{array}{l}\text { Shelled melon (kernels) } \\
\text { Variable cost (N) }\end{array}$ & $\$ 450 / m u d u$ \\
\hline Quantity of unshelled melon (mudus/five days) & 600 (10 bags) \\
\hline Purchase (unshelled melon @ $¥ 8,000 /$ bag) & $80,000.00$ \\
\hline Market levy & 50.00 \\
\hline Petrol/diesel and oil & $2,400.00$ \\
\hline Labour (wages) & 2000.00 \\
\hline Transportation & $1,320.00$ \\
\hline Miscellaneous & 1700.00 \\
\hline Total Variable Cost (TVC) & $87,570.00$ \\
\hline \multicolumn{2}{|l|}{ Revenue ( } \\
\hline Average output (mudus/every five days) & 300 (5bags) \\
\hline Total sales of shelled melon (TR) & $135,000.00$ \\
\hline Gross Margin (GM = TR - TVC) & $47,530.00$ \\
\hline
\end{tabular}




\subsection{Hypotheses Testing}

\subsubsection{Test of Significance Difference in the Melon Processed before and after the Technology Adoption}

Result of the t-test in Table 3 shows that there is significant difference in the melon processed before and after technology adoption $(\mathrm{t}=-22.27, \mathrm{p}=0.02)$ at $\mathrm{p}<0.05$ level of significance. This indicates that quantity of melon processed before and after the technology adoption varies, that is, technology adoption leads to higher productivity. It can be inferred from the previous result in Table 1 that the variation is due to higher quantity of melon being processed (above 190kg/day) after the technology adoption. Therefore, the null hypothesis that "there is no significant difference in the melon processed before and after the technology adoption" is rejected.

Table 3: t-test result of significant difference between the melon processed before and after technology adoption

\begin{tabular}{llllllllll}
\hline Variables & $\begin{array}{l}\text { Sample } \\
\text { size }\end{array}$ & df & Mean & $\begin{array}{l}\text { Std. } \\
\text { Dev. }\end{array}$ & Std. Mean Error & $\begin{array}{l}\text { Mean } \\
\text { diff. }\end{array}$ & t & p-value & Decision \\
\hline Before & 190 & 189 & 45.23 & 2.11 & 0.06 & 0.31 & -22.27 & 0.02 & $\mathrm{~S}$ \\
After & 190 & 189 & 67.50 & 2.42 & 0.09 & & & & \\
\hline
\end{tabular}

Source: Field Survey, 2016. S - Significant at $\mathrm{p}<0.05$ level of significance

\subsubsection{Linear Regression of Relationship between Quantities of Melon Processed with Improved Technology and Economic Returns}

The $\mathrm{R}^{2}$ of linear regression model in Table 4 indicates that $72 \%$ variation in the economic returns is caused by the explanatory variable. The significant F-statistic further indicated that the null hypothesis $\left(\mathrm{H}_{02}\right)$ in the sample remained rejected at $1 \%$ level of significance. Significant relationship existed between quantity of melon processed $(\mathrm{t}=37.03)$ and economic returns at $\mathrm{p}<0.05$. This implies that for every $1 \%$ increment in quantity of melon processed there will be $37 \%$ increment in economic returns obtained by the melon processors. Therefore, the null hypothesis $\left(\mathrm{H}_{02}\right)$ that "there is no significant relationship between quantity of melon processed with improved technology and economic returns" is rejected.

Table 4: Relationship between quantity of melon processed and economic returns

\begin{tabular}{lllll}
\hline Variables & Estimate & Std. Error & t-value & $\operatorname{Pr}(>|\mathbf{t}|)$ \\
\hline (Constant ) & 35.20 & 0.5231 & 67.29 & $<2 \mathrm{e}^{-16 * * *}$ \\
Quantity of melon processed & 24.07 & 0.65 & 37.03 & $0.000^{* * *}$ \\
Model Fit Tests & & & & \\
F-statistics & 561.8 & & & \\
$\mathrm{R}^{2}$ & 0.72 & & & \\
Adjusted R & & & \\
Prob(F-Statistics) & 0.70 & & & \\
\hline Source: Field Survey, 2016 & & & & \\
$* * *$ Significant at 1\% level & & & &
\end{tabular}

\section{Conclusion}

It can be concluded that adoption of improved melon processing technology led to increased production output and high economic returns for the rural women. There is significant difference in the melon processed before and after the technology adoption. Significant relationship existed between quantity of melon processed with improved technology and economic returns. The implication is that adoption of improved technology has contributed positively to the economic returns of melon processors, thereby easing their economic hardship and poverty. The study recommends that government should intensify effort to produce more improved melon processing technology for the rural women; and rural women should continue to adopt improved melon processing technology to boost their productivity and economic returns. 


\section{References}

1. Ajibola, O. O., Eniyemo, S. E., Fasina, O. O. and Adeeko, K. A. 1990. Mechanical Expression of Oil from Melon Seeds. Journal of British Society of Research in Agricultural Engineering, 45 (1): 45-53.

2. Aniedu, C. 2006. Gender Factors in Access and Use of Improved Yam Technologies by Farmers in South-eastern Agricultural zone of Nigeria. Unpublished Ph.D. Thesis, Michael Okpara University of Agriculture, Umudike. Pp $1-50$.

3. Atanda, S. A., Pessu, P. O., Agoda, S., Isong, I. U. and Ikotun, I. 2011: The concepts and problems of postharvest food losses in perishable crops. African Journal of Food Science, 5 (11): 603-613.

4. Ayittey G. B. N. 2005. African Unchained: The Blueprint for Africa's Future. New York, Palgrave Macmillan.

5. Ayodele, O. J. and Shittu, O. S. 2013. Cost-benefit analysis of melon (egusi) seed and seed-oil yield responses to phosphorus fertilizer application. International Research Journal of Agricultural Science and Soil Science, 3(5): 152-155.

6. Donkoh, S. A. 2006. Technology Adoption and efficiency in Ghanaian Agriculture. Unpublished PhD Thesis, Department of Agriculture and Food Economics, The University of Reading, UK.

7. Ezeh, C. I. and Nwachukwu, I. N. 2007. Impact of Selected Rural Development Programmes on Poverty Alleviation in Ikwuano Local Government Area, Abia State, Nigeria. African Journal of Food Agriculture Nutrition and Development, 7 (5): $11-17$.

8. Fadilah, M. Seth, B. and Seidu, A. 2013. Effects of Adoption of Improved Sheabutter Processing Technology on Women's Livelihoods and their Microenterprise Growth. American Journal of Humanities and Social Sciences, $1(4): 244-250$.

9. Hart, A. O., Ajubuike, C. U., Barimaala, I. S., and Achienwhu, S. C. 2005. Vegetable consumption pattern of household in selected areas of the old River State, Nigeria. African Journal of Food Nutrition and Development, 5(1): www.ajfand.net/index/html

10. James, K. M., Umogbai, V. and Itodo, I. N. 2011. Development and evaluation of a melon shelling and cleaning machine. Journal of Emerging Trends in Engineering and Applied Sciences 2: 383-388.

11. Mohammed, B. T. 2011. Socio-economic analysis of melon production in Ifelodun Local Government Area, Kwara State, Nigeria. Journal of Development and Agricultural Economics, 3(8): 362-367.

12. Mohammed, B. T., Achem, B. A. and Abdulquadri, A. F. 2014. Factors Influencing Adoption of Agricultural Processing Technologies Developed by National Centre for Agricultural Mechanization (NCAM) in Ifelodun Local Government Area, Ilorin Kwara State. International Journal of Science and Research, 3(4): 3 - 5 .

13. Niger State, Online Nigeria. Community Portal of Nigeria, 2003.

http://www.onlinenigeria.com/links/nigeradv.asp? blurb=335

NPC (National Population Center). 2006. Legal Notice of Publication of 2006 Census Final Result. Federal Republic of Nigeria Official gazette: Federal Capital Territory Abuja.

14. Nwanyanwu, D. H., Amadi, C. and Nyekachi, A. 2014. Assessment of farm outputs and rural income generation of School to Land Agricultural Programme (STLAP) in River State, Nigeria. Journal of Biology, Agriculture and Healthcare, 4(14): $126-134$.

15. Ofoh, M. C. 2009. Food security and mitigation of climate change through Ecosystem based Agriculture, 13th inaugural lecture of the Federal University of Technology Owerri (FUTO), Imo State. pp. $24-27$.

16. Onwualu, A. P. 2010. Promoting Agro and Allied Industry through effective Research, Processing and Packaging of Agricultural Products. Presented at the $1^{\text {st }}$ National Agricultural Symposium organized by Enugu Chamber of Commerce, Industry, Mines and Agriculture on 28th - 29th September, 2010 held at Nike Lake Resort Hotel, Enugu.

17. Ross, K. 2012. Technology and yield gaps in food production. Westernfarmpress.com. September 17, 2012. Accessed on $18^{\text {th }}$ February, 2014.

18. Sobowale, S. S., Adebiyi, J. A. and Adebo, O. A. 2015. Design, Construction and Performance Evaluation of a Melon Seeds Sheller. Journal of Food Processing Technology, 6 (7): 463-467.

19. Thisdaylive, 11 April 2013. Leaning towards mechanized farming and agri-business.www.thisdaylive.com.

20. World Bank, 2009. Gender in Agriculture Sourcebook: Agriculture and Rural Development Series. Washington, DC: The World Bank. 